\title{
NEO-SKEPTISISME MICHAEL COOK DAN NORMAN CALDER TERHADAP HADIS NABI MUHAMMAD
}

\author{
Ali Masrur \\ Universitas Islam Negeri Sunan Gunung Djati Bandung \\ e-mail: alimasrur@yahoo.com
}

\begin{abstract}
This writing studies the ideas of renewed skepticism of Michael Cook and of Norman Calder to the prophetic hadith and to the validity of common link theory. By using the method of comparative analysis, it is found that Cook and Calder are highly skeptical to the prophetic hadith and to the validity of common link theory. Cook and Calder's skepticism even exceed Goldziher's and Schacht's skepticism. Cook and Calder say that common link phenomenon did not indicate that a certain hadith is originated from a key or a common transmitter, but it is the result of a different scenario of the spread of isnād and the result of competition of isnād criticism in the schools of Islamic law (madzāhib) in early Islamic society. Both Cook and Calder hesitate the truth and the validity of common link theory. Therefore, according to them, common link method cannot be used to trace the origin, provenance, and authorship of early hadith.
\end{abstract}

\begin{abstract}
Abstrak: Tulisan ini mengkaji ide-ide neo skeptisisme Michael Cook dan Norman Calder terhadap hadis Muhammad. dan terhadap validitas teori common link. Dengan menggunakan metode analisa komparatif, ditemukan bahwa Cook dan Calder sangat skeptis terhadap hadis Nabi Muhammad. Terhadap validitas teori common link. Skeptisisme Cook dan Calder bahkan melebihi skeptisisme Goldziher dan Schacht. Cook dan Calder berpendapat bahwa fenomena common link tidak menunjukkan bahwa sebuah hadis tertentu itu bersumber dari seorang periwayat kunci atau periwayat bersama, tetapi ia merupakan akibat dari skenario yang berbeda mengenai penyebaran isnād dan akibat dari kompetisi isnād di berbagai aliran fikih Islam (madhāhib) dalam masyarakat Islam awal. Baik Cook dan Calder sama-sama meragukan kebenaran dan validitas teori common link. Oleh karena itu, menurut mereka, metode common link tidak dapat digunakan untuk menelusuri asal mula, sumber dan kepengarangan hadis di masa awal.
\end{abstract}

Keywords: neo-skeptisisme; teori the spread of isnād; teori common link; kritik isnād; teori pertumbuhan organik

\section{A. Pendahuluan}

Kajian hadis di dunia Barat telah berkembang menjadi empat fase. Pertama, fase skeptisisme Barat awal yang berusaha meragukan autentisitas hadis dengan argumentasi bahwa telah terjadi pemalsuan besar-besaran dalam sejarah periwayatannya. Kedua, fase reaksi terhadap skeptisisme Barat yang menjawab 
berbagai kritik dan tuduhan para revisionis Barat terhadap hadis Nabi Muhammad. Ketiga, fase upaya mencari jalan tengah yang, di satu sisi, ada persamaan dengan para pemikir revisionis Barat, tetapi, di sisi lain, hasil temuannya berdiri di jalan tengah antara dua paradigma di atas: paradigma revisionis dan paradigma tradisional. Adapun yang keempat adalah fase neo-skeptisisme Barat yang berupaya untuk meragukan hadis Nabi dengan mengembangkan metode para revisionis Barat atau menggunakan metodenya sendiri. Tokohtokoh yang termasuk ke dalam fase keempat ini adalah Michael A. Cook dan Norman Calder. ${ }^{1}$

Michael Cook mengatakan dalam Early Muslim Dogma, munculnya fenomena common link adalah akibat dari proses penyebaran isnād dalam skala besar. Fenomena common link tidak menunjukkan bahwa sebuah hadis benarbenar bersumber dari seorang periwayat kunci. ${ }^{2}$ Oleh karena itu, metode common link yang dikembangkan oleh Juynboll tidak dapat dipakai untuk menelusuri asal-usul, sumber, dan kepengarangan hadis pada masa awal Islam.

Norman Calder mengingkari bahwa metode common link itu dapat dipakai untuk mengetahui penanggalan hadis. Baginya, fenomena common link sebagai satu ciri yang terdapat dalam literatur hadis sangat terkait dengan kompetisi antar berbagai kelompok di kalangan para ahli hukum dan yang lainnya pada paroh kedua abad ketiga hijriah yang masing-masing terlibat dalam proses kritik isnād satu sama lain. ${ }^{3}$

Dua pandangan ini pada gilirannya mengejutkan para pengkaji hadis pada khususnya dan umat Islam pada umumnya. Oleh karena itu, artikel ini mengkaji pandangan neo-skeptisisme Michael Cook dan Norman Calder tentang hadis, khususnya tentang teori common link. Pembahasan tentang ide-ide Cook dan Calder ini tentunya merupakan fase akhir dari beberapa fase perkembangan studi hadis di Barat. Keduanya dapat dipandang sebagai wakil dari fase keempat, yakni fase neo-skeptisisme. Meskipun pandangan Cook dan Calder tampak sangat spekulatif dan tidak berpijak pada fakta-fakta historis yang kuat, tetapi

${ }^{1}$ Herbert Berg, the Development of Exegesis in Early Islam: the Authenticity of Muslim Literature from the Formative Period (Surrey: Curzon Press, 2000), h. 8-64; Ali Masrur. Teori Common link G.H.A Juynboll: Melacak Akar Kesejarahan Hadits Nabi (Yogyakarta: LKiS, 2007), h. 33-48.

2Michael A. Cook, Early Muslim Dogma: A Source Critical Study (Cambridge: Cambridge University Press, 1981), h. 107-109.

${ }^{3}$ Norman Calder, Studies in Early Muslim Jurisprudence (Oxford: Oxford University Press, 1993), h. 240. 
interpretasinya tentang fenomena common link merupakan ide orisinal. Oleh karena itu, perlu dilakukan kajian terhadap pandangan dua tokoh ini. Jadi, yang menjadi masalah dalam penelitian ini adalah: 1) Bagaimana pandangan neoskeptisisme Cook dan Calder terhadap hadis Nabi Muhammad? 2) Apa persamaan dan perbedaan pandangan neo-skeptisisme Cook dan Calder?

Tujuan mengkaji dua tokoh ini adalah: pertama, untuk mengetahui perkembangan terakhir dan terbaru kajian hadis di dunia Barat; kedua, untuk mengkritisi pandangan Cook dan Calder yang bersifat hiper-skeptisisme terhadap hadis Nabi Muhammad. Sedangkan kegunaan penelitian ini di antaranya adalah: pertama, untuk memberikan kontribusi kepada pengembangan kajian hadis dan ilmu hadis yang selama ini dianggap tidak berkembang; kedua, untuk memberikan pengayaan dan penguatan kepada studi hadis dan ilmu hadis dengan berbagai teori dan metode baru dari dunia Barat yang masih dipandang sebelah mata oleh para sarjana Muslim.

Dengan menggunakan metode analisa komparatif, pandangan Michael Cook tentang hadis Nabi Muhammad. dibandingkan dengan pandangan Norman Calder dalam hal yang sama. Hal ini dilakukan untuk mengetahui persamaan dan perbedaan di antara keduanya. Perbandingan dilakukan dengan cara membandingkan gagasan umumnya, metodologi dan pendekatan yang digunakannya, titik tolak kajiannya, sumber-sumber kajiannya dan buku-buku yang mempengaruhinya. ${ }^{4}$

Sumber data untuk mengetahui pandangan neo-skeptisisme Cook terhadap hadis Nabi Muhammad adalah karya utama Michael Cook, Early Muslim Dogma: A Source Critical Study. Cambridge: Cambridge University Press, 1981. Sedangkan untuk mengetahui ide-ide neo-skeptisisme Calder terhadap hadis Nabi Muhammad, dapat diketahui dengan mengkaji karya monumental Norman Calder, Studies in Early Muslim Jurisprudence. Oxford: Oxford University Press, 1993. Untuk memperluas kajian ini, karya-karya Cook dan Calder yang lain juga tidak dapat diabaikan. Data-data yang relevan dengan masalah penelitian ini dalam karya-karya itu dapat dipakai sebagai pelengkap dan pendukung. Tidak kalah pentingnya adalah tulisan-tulisan orang-orang tentang Cook dan Calder. Tulisan-tulisan ini adalah sumber ketiga yang dapat membantu menjelaskan ide-ide neo-skeptisisme Cook dan Calder.

${ }^{4} J u j u n$ S. Suriasumantri, "Penelitian Ilmiah, Kefilsafatan, dan Keagamaan: Mencari Paradigma Kebersamaan, " dalam Mastuhu dan M. Deden Ridwan (ed.), Tradisi Baru Penelitian Agama Islam: Tinjauan antar Disiplin Ilmu (Bandung: Nuansa, 2001), h. 68-75. 


\section{B. Biografi dan Karya-karya Michael Allan Cook}

Michael Allan Cook dilahirkan pada tahun 1940 M. di Inggris. Ia adalah seorang sejarawan berkebangsaan Inggris-Scotlandia dan seorang sarjana di bidang sejarah Islam dan sejarah hadis dari Universitas Princeton, New Jersey. Ia menulis sebuah buku bersama Patricia Crone yang berjudul Hagarism: The Making of the Islamic World. Michael A. Cook mendapatkan pendidikannya di Universitas Cambridge (yang berada di Cambridge, bukan yang di Massachusetts). Ia belajar sejarah dan studi-studi ketimuran di King's College, Cambridge 19591963. Ia menggunakan waktu dua tahun untuk mempelajari sejarah Inggris dan Eropa dan dua tahun untuk belajar Turki dan Persia. Dari sana, ia melanjutkan ke studi Pascasarjana di School of Oriental and African Studies (SOAS), Universitas London pada tahun 1963-1966 di bawah bimbingan Prof. Bernard Lewis, di mana ia memulai penelitian tentang sejarah populasi kerajaan Utsmani di abad lima belas dan enam belas. Kemudian, ia menggunakan waktu beberapa tahun untuk menjadi dosen dan peneliti di bidang sejarah Islam di School of Oriental and African Studies, pada tahun 1966-1984 dan seorang pengkaji sejarah Timur Dekat dan Timur Tengah pada tahun 1984-1986, hingga di tahun 1986, ia dipilih oleh Cleveland E Dodge, seorang Profesor studi-studi Timur Dekat untuk menerima jabatan di Universitas Pricenton. ${ }^{5}$

Ketika ia memulai penelitiannya, telah diketahui secara umum bahwa sejarah yang benar-benar dianggap adalah sejarah ekonomi dan sosial yang dikaji dengan menggunakan metode kuantitatif yang tepat. Sejak saat itu, pengetahuan umum tersebut telah bergeser dan begitu juga interest penelitiannya. Sebagian besar yang dipublikasikan olehnya terkait dengan persoalan pembentukan peradaban Islam, dan peranan yang dimainkan oleh nilai-nilai keagamaan dalam proses tersebut. Belakangan ini, ia telah menerbitkan sebuah monograf tentang sebuah nilai Islam: konsep amar ma'ruf nahyi munkar Memerintah kebaikan dan melarang hal-hal yang bertentangan dengan hukum Tuhan (munkar). Ia juga memiliki beberapa makalah yang terpencar yang belum selesai mengenai beberapa topik ${ }^{6}$

5Michael A. Cook, Oposisi Penulisan Hadits di Masa Islam Awal, terj. Ali Masrur Abdul Ghaffar. (Bandung: Marja Nuansa Cendekia, 2012), h. 169; http://en.wikipedia.org/wiki/Michael_Cook_\%28 historian\%29.

${ }^{6}$ Ibid. 
Matakuliah yang diajarkannya di program pascasarjana cenderung disesuaikan dengan ketertarikannya sendiri dan ketertarikan mahasiswa pascasarjana. Ia lebih suka mengajar matakuliah-matakuliah yang terpusat pada teksteks berbahasa Arab dan dirancang untuk memberikan penjelasan kepada mahasiswa pascasarjana tentang praktik mencari dan menemukan sumbersumber primer. Ia mengajar sejarah Islam di abad-abad awal. Ia mengajar matakuliah ini setiap tahun dan seringkali diambil oleh mahasiswa pascasarjana dengan upgrade yang sesuai. Ia juga menawarkan matakuliah baru untuk program sarjana tentang sejarah dunia hingga ekspansi Eropa. Ia berharap, matakuliah ini akan memberi keuntungan bagi para mahasiswa pascasarjana untuk mengamati sejarah Islam.

Ia telah membimbing beberapa disertasi sejak ia mengajar di Universitas Princeton. Beberapa orang yang telah dibimbing disertasinya oleh Michael Cook di antaranya adalah Michael Bonner yang menulis disertasi tentang Garis Perbatasan Bizantium-Arab di zaman Abbasiyah awal. Keith Lewinstein menulis disertasi tentang analisa terhadap pembentukan dan transmisi literatur heresiografi Islam di masa awal. Jon Katz mengkaji buku harian yang berisi mimpi-mimpi seorang sufi Afrika Utara yang eksentrik di akhir abad pertengahan. Yitzhak Nakash yang eksentrik di akhir abad pertangahan. Yitzhak Nakash meneliti interaksi Syi'isme dan identitas nasional di Irak modern. Nurit Tsafrir menulis tentang penyebaran awal aliran fikih Hanafi. David Manner meneliti budaya politik pengadilan di zaman Abbasiyah di akhir abad ketiga dan awal abad keempat hijrah. Nimrod Hurvitz mengkaji Ibnu Hanbal dan pembentukan ortodoksi Islam. Adam Sabra menulis disertasi tentang kemiskinan dan kedermawanan di kerajaan Mamluk Kairo. Adrien Leites menganalisa hadis-hadis tentang jam dan malam dilahirkannya Nabi Muhammad. Ronen Raz mengkaji reaksi para intelektual Arab terhadap orientalisme pasca periode 1798-1950. Shahab Ahmed meneliti berbagai cerita awal tentang insiden Satanic Verses. Disertasi-disertasi tersebut menjelaskan wilayah-wilayah kajian apa saja yang ia ketahui. ${ }^{7}$

Michael Cook sebagai seorang ilmuwan kelas dunia telah berhasil meraih beberapa penghargaan dan nominasi sebagai berikut: 1) Pada tahun 2001, ia terpilih menjadi anggota American Philosophical Society. 2) Pada tahun 2002, ia menerima hadiah sebesar \$ 1,5 juta sebagai hadiah prestasi terhormat dari

${ }^{7}$ Ibid. 
Mellon Foundation karena sumbangannya yang signifikan kepada penelitian di bidang ilmu humaniora. 3) Pada tahun 2004, ia terpilih sebagai anggota American Academy of Arts and Sciences. 4) Pada tahun 2006, ia memenangkan hadiah Howard T. Behrman sebagai hadiah prestasi terhormat di bidang ilmu humaniora di Princeton. 5) Pada tahun 2008, ia memenangkan hadiah Farabi di bidang ilmu humaniora dan studi-studi keislaman. ${ }^{8}$

Michael Cook telah menghasilkan banyak karya yang meliputi berbagai persoalan seperti, sejarah Islam, ilmu kalam, al-Qur'an, sejarah hadis, kebudayaan Islam, dan yang terakhir adalah sejarah ras manusia. Karya-karya itu di antaranya: 1) Population Pressure in Rural Anatolia, 1450-1600, London, 1972. 2) Hagarism: The Making of the Islamic World. Cambridge, 1977. 3) "The Origin of Kalam," in Bulletin of the School of Oriental and African Studies, 43 (1980). 4) Early Muslim Dogma: A Source Critical Study, Cambridge, 1981. 5) "Pharaonic History in Medieval Egypt", Studia Islamica 57(1983). 6) Muhammad (Fast Masters), 1983. 7) "Magian Cheese: an Archaic Problem in Islamic Law," in Bulletin of the School of Oriental and African Studies, 47 (1984). 8) "The Expansion of the First Saudi State: the Case of Washm," in C.E. Bosworth and Others (eds.), The Islamic World from Classical to the Modern Times: Essays in Honor of Bernard Lewis, Princeton, 1989. 9) "Eschatology and the Dating of Tradition," in Princeton Papers, 1 (1992). 10) "Ibn Qutayba and the Monkeys," in Studia Islamica, 89 (1999). 11) The Koran (in the OUP "Very Short Introduction" series, Oxford, 2000.12) Commanding Right and Forbidding Wrong in Islamic Thought, Cambridge, 2000. 13) Forbiding Wrong in Islam: An Introduction (Themes in Islamic History), 2003. 14) Studies in the Origin of Early Islamic Culture and Tradition, 2004. 15) A Brief History of the Human Race, 2005.

\section{Pandangan Michael A. Cook tentang Common Link sebagai Akibat dari Proses Penyebaran Isnād}

Dalam Early Muslim Dogma, Cook mengkaji persoalan penanggalan (dating) hadis, dan menantang temuan-temuan Joseph van Ess mengenai asalusul dan perkembangan kontroversi Jabariah dan Qadariah pada masa Islam awal. Cook mengakui bahwa metode van Ess adalah metode seorang orientalis:

8http://en.wikipedia.org/wiki/Michael_Cook_\%28historian\%29. 
seseorang tidak memberi penanggalan pada hadis hanya berdasarkan penyandaran seperti dalam isnād. Menurut Cook, van Ess, seperti halnya Schacht, mengakui bahwa isnād telah berkembang ke belakang dan ia juga menerima validitas teori common link. Sebagaimana telah dijelaskan di atas bahwa ketika berbagai isnād dari matan hadis yang sama tampak bercabang atau menyebar dari seorang periwayat tertentu, maka periwayat tersebut berperan sebagai titik pindah bersama (terminus ante quern). ${ }^{9}$

Untuk mengkritik metode common link, Cook mengembangkan dan memperluas teori Schacht yang lain, yakni teori penyebaran isnād (the spread of isnāds). Teori ini mengatakan bahwa para periwayat hadis terbiasa menciptakan isnād-isnād tambahan untuk mendukung sebuah matan hadis yang sama.10 Menurut Cook, munculnya fenomena common link adalah akibat dari proses penyebaran isnād dalam skala besar. Fenomena common link tidak menunjukkan bahwa sebuah hadis benar-benar bersumber dari seorang periwayat kunci. Oleh karena itu, metode common link yang dikembangkan oleh Juynboll tidak dapat dipakai untuk menelusuri asal-usul, sumber, dan kepengarangan hadis.

\author{
Muhammad \\ । \\ Ibnu Abbas \\ Ibnu Jubair \\ Ibnu Juraij
}

Diagram 1

Proses penyebaran isnād paling tidak dapat terjadi dalam tiga cara pertama, melompati periwayat yang sezaman; kedua, menyandarkan hadis pada seorang guru yang berbeda; ketiga, mengatasi persoalan hadis-hadis yang "terisolasi".

\footnotetext{
${ }^{9}$ Michael A. Cook, Early Muslim Dogma..., h. 107-108.

${ }^{10}$ Joseph Schacht, The Origins of Muhammadan Jurisprudence (Oxford: Clarendon Press, 1950), h. 166; Schacht mengatakan, "Parallel with the improvement and backward growth of isnāds goes their spread, that is the creation of additional authorities or transmitters for the same doctrine or tradition."
} 
Pada proses pertama, misalnya, Ibnu Jubair dan Ibnu Juraij adalah kawan sezaman dan kemudian Ibnu Juraij belajar hadis kepada Ibnu Jubair. Lalu Ibnu Jubair mengatakan bahwa ia memperoleh hadis itu dari gurunya, Ibnu Abbas. Jika Ibnu Juraij adalah seorang yang jujur dan dapat dipercaya maka ia akan meriwayatkan hadis itu dari Ibnu Jubair dari gurunya, Ibnu Abbas. ${ }^{11}$ Dengan proses seperti ini, muncullah isnād sebagaimana Diagram 1.

Meskipun Ibnu Juraij tidak mendengar secara langsung dari Ibnu Abbas, guru Ibnu Jubair, bisa saja ia tidak meriwayatkannya dari kawan sezamannya, Ibnu Jubair, tetapi langsung dari gurunya, Ibnu Abbas dengan cara meloncatinya. Sikap seperti itu didasari oleh keyakinan bahwa isnād yang baik adalah isnād yang pendek karena secara ideal, seseorang seharusnya mendengarkan sebuah hadis secara langsung dari orang yang mengatakannya. Semakin sedikit periwayat yang ada dalam rangkaian jalur periwayat, semakin baik isnād-nya, ${ }^{12}$ sehingga diagram isnād di atas (Diagram 1) berubah menjadi seperti pada Diagram 2.

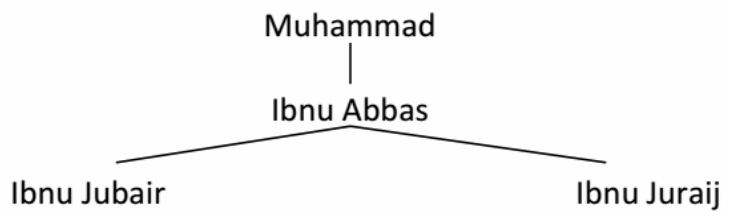

\section{Diagram 2}

Proses kedua bagi penyebaran isnād adalah sebagai berikut: misalnya, Abdullah menyampaikan sebuah matan hadis kepada Ibnu Sa'id yang ia dengar dari Ibnu Jubair. Ia sendiri menerimanya dari Ibnu Abbas (simak Diagram 3). Daripada mengklaim telah mendengar hadis dari Ibnu Jubair, guru Abdullah, Ibnu Sa'id menyandarkan hadis dari Ibnu Abbas itu kepada gurunya sendiri, Ibnu Juraij (seperti pada Diagram 4). Ini dilakukan oleh Ibnu Sa'id karena ia mungkin tidak pernah bertemu dengan Ibnu Jubair, atau Ibnu Jubair tidak dianggap sebagai periwayat yang dapat diterima oleh kelompok Ibnu Sa'id.

11Michael Cook, Early Muslim Dogma, h. 109.

${ }^{12}$ Herbert Berg, The Development of Exegesis in Early Islam..., h. 43. 
Untuk menghindari persoalan ini, ia menyandarkan hadis itu kepada gurunya sendiri, Ibnu Juraij.13 Ini mengakibatkan isnād hadis itu bercabang dan membentuk Diagram 3:

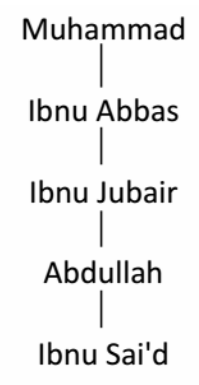

\section{Diagram 3}

Adapun yang ketiga adalah proses yang diidentifikasi oleh Schacht sendiri sebagai yang bertanggung jawab atas penyebaran Isnād. Ia mengatakan bahwa penyebaran isnād dimaksudkan untuk mengatasi keberatan-keberatan atas hadis-hadis yang "menyendiri" (infirad). ${ }^{14}$ Hadis-hadis yang menyendiri (khabar al-wahid, khabar al-infirad) tidak dapat diterima sebagai hadis autentik karena, dalam pandangan kelompok anti-ahli hadis, sebuah hadis dapat diterima jika diriwayatkan setidak-tidaknya oleh dua orang saksi yang dapat dipercaya. Hadis yang didasarkan atas pernyataan seorang periwayat dapat diterima jika dikuatkan dengan sumpah. ${ }^{15}$ Akibatnya, muncul motivasi yang sangat kuat untuk menemukan atau menciptakan isnād-isnād yang lain.

Tiga skenario bagi penyebaran atau penciptaan isnād-isnād baru ini, khususnya yang pertama dan kedua, mengakibatkan terjadinya fenomena common link dalam proses periwayatan hadis. Pada Diagram 2 dan 4, tampak jelas bahwa isnād hadis itu mulai menyebar ke beberapa murid dari Ibnu Abbas. Dengan demikian, menurut asumsi Juynboll, Ibnu Abbas adalah pencetus (originator) hadis tersebut. Akan tetapi, menurut Cook, tersebarnya isnād dari seorang periwayat kunci ke sejumlah periwayat tidak menunjukkan asal-usul

${ }^{13}$ Cook, Early Muslim Dogma, h. 110; Herbert Berg, The Development of Exegesis, h. 43-44.

${ }^{14}$ Michael Cook, Early Muslim Dogma, h. 110; Joseph Schacht, The Origins.... h. 166.

${ }^{15}$ Joseph Schacht, The Origins..., h. 50. Perhatikan bahwa Umar tidak puas dengan informasi dari pribadi tunggal yang menceritakan keputusan nabi, tetapi meminta konfirmasi dari orang lain. 
dan sumber hadis karena pada dasarnya semua isnād adalah palsu kecuali satu saja, sebagaimana dijelaskan di depan.

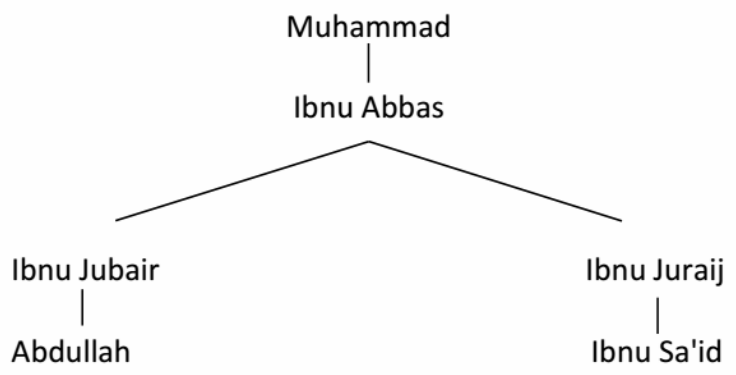

\section{Diagram 4}

Jadi, teori penyebaran isnād dalam pandangan Cook sebenarnya telah merusak teori common link dan membuatnya tidak dapat dioperasikan lagi. Jika tiga skenario di atas terjadi dalam skala luas maka dengan sendirinya skenario itu meruntuhkan upaya apa pun untuk menggunakan isnād sebagai alat untuk menelusuri asal-usul hadis. Cook menyatakan bahwa upaya untuk menyelidiki kronologi hadis dengan metode common link seperti dilakukan van Ess dan Juynboll adalah salah. Baginya, interpretasinya mengenai fenomena common link lebih merupakan penghancuran informasi daripada memberikan informasi. ${ }^{16}$

Cook juga menyadari argumen Azami yang menentang Schacht tentang autentisitas hadis. Azami menyatakan bahwa banyak hadis diriwayatkan oleh sejumlah orang Muslim dari setiap generasi di berbagai daerah di negara Muslim. Bahwa masing-masing periwayat mengambil hadis-hadis yang samasama dipalsukan, mensyaratkan adanya tindakan konspirasi yang secara historis sangat tidak masuk akal. ${ }^{17}$ Menanggapi hal ini, Cook menyatakan bahwa, jika proses penyebaran isnād itu dipercayai telah benar-benar terjadi dalam

\footnotetext{
${ }^{16}$ Michael Cook, Early Muslim Dogma, h. 116; Herbert Berg, The Development of Exegesis, h. 4445; Kamaruddin Amin, "Western Method of Dating vis-a-vis Ulumul Hadits: Refleksi Metodologis atas Diskursus Kesarjanaan Hadits Islam dan Barat." UIN Alaudin Makasar: Pidato Pengukuhan Jabatan Guru Besar, 2010. Makalah belum diterbitkan. 13-14.

${ }_{17}$ M.M. Azami, Studies in Early Hadith Literature with Critical Edition of Some Early Text (Beirut: al-Maktab al-Islami), 1968, h. 222-247; Herbert Berg, The Development of Exegesis, h. 45.
} 
skala yang signifikan, maka argumen Azami tidak menyentuh kita. Akan tetapi, jika tidak, argumennya tidak dapat ditolak. Oleh karena itu, tentang persoalan ini, pilihannya adalah antara Schacht dan al-Syafi'i tidak ada metodologi jalan tengah. ${ }^{18}$

Berkaitan dengan serangan Cook ini, Juynboll mencoba mempertahankan metode common link dengan mengemukakan dua argumen: pertama, model konstruksi Cook tentang penyebaran isnād, kata Juynboll, memang sering kali terjadi dan merupakan penyebab bagi perkembangan isnād. Meski demikian, jika kejadian ini benar-benar dilakukan oleh sejumlah besar periwayat yang sezaman secara bersamaan maka ia seharusnya meninggalkan kesaksiankesaksian dalam berbagai sumber rijāl. Gagasan tentang adanya konspirasi untuk memalsukan hadis juga ditolak karena jika benar maka tentu ada tandatanda dalam sumbernya. ${ }^{19}$

Kedua, apabila sejumlah periwayat hadis berasal dari satu orang dan atas dasar prinsip Cook ditegaskan bahwa semua jalur periwayatan adalah palsu, kecuali satu, maka fenomena kebetulan (coincidence) semacam ini harus dijelaskan, yakni mengapa sejumlah murid, masing-masing dengan alasannya sendiri dan bekerja sendiri-sendiri tanpa diketahui oleh sesama murid, berlagak seolah-olah menerima hadis yang sama dari seorang guru yang sama? Menurut Juynboll, fenomena kebetulan seperti ini sulit diterima. Berkaitan dengan hal ini Juynboll menyatakan:

"Adalah lebih masuk akal untuk melihatnya sebagai jalur historis dari seorang syaikh ke sejumlah muridnya yang semuanya mengaku bahwa mereka telah mendengar hadis tertentu dari syaikh itu. Dan, Cook cenderung setuju bahwa semakin banyak jalur periwayatan bertemu di satu titik, semakin kecil kemungkinan prinsipnya dapat diterapkan pada titik itu. Makin bersimpul suatu jalur periwayatan, makin masuk akal kesejarahannya."20

Atas keberatan Juynboll ini, Cook memberikan tanggapan yang terlalu singkat sehingga tampak kurang meyakinkan. Pertama, jika penyebaran isnād itu merupakan argumen yang benar dan dapat diterima maka seharusnya ia

${ }^{18} \mathrm{On}$ this issue, the choice is between Schacht and Shafi'i; there is no methodological middle ground; lihat Michael Cook, Early Muslim Dogma, h. 116.

${ }^{19}$ G.H.A. Juynboll, "Some Isnad-Analytical Methods", h. 355.

20 Ibid. 
diterapkan pada jalur-jalur pemalsuan hadis yang dipakai Juynboll untuk menyusun bundel isnād yang menuju pada ahli hadis yang sama sebagai common link. Kedua, apa yang dapat digambarkan dari penyebaran isnād adalah sebuah proses peniruan (a process of imitation), bukan sebuah kebetulan. Kalau para periwayat itu benar-benar bekerja sendiri-sendiri maka tentunya mereka tidak meminjam hadis dari periwayat yang lain. ${ }^{21}$ Sayangnya, Cook sendiri tidak yakin apakah proses penyebaran isnād dalam faktanya benar-benar terjadi dalam skala luas atau tidak.

Di sisi lain, Motzki berpendapat, prinsip Cook tentang penyebaran isnād tidak dapat diterima. Adanya kemungkinan, atau bahkan kemasukakalan, bahwa isnād-isnād tambahan telah diciptakan dan kenyataan bahwa "penyebaran isnād telah terbukti kebenarannya dalam kasus-kasus individual, hal itu tidak dengan sendirinya mengabsahkan generalisasi prinsip tersebut dan mendevaluasi sistem isnād secara keseluruhan. Hal ini disebabkan karena maksud sistem isnād adalah untuk meyakinkan reliabilitas proses periwayatan. Nilai dasarnya adalah bahwa seseorang harus menyebutkan nama informannya yang darinya ia mendapatkan informasi itu. Melakukan hal yang sebaliknya adalah pemalsuan dan ketidakjujuran. Hal ini jelas diketahui oleh para ahli hadis yang akrab dengan sistem itu.

Kesimpulan bahwa sistem isnād secara umum tidak dapat dipercaya dan tidak dapat dipakai untuk penanggalan hadis karena adanya beberapa periwayat yang tidak jujur dan adanya isnād-isnād palsu dapat dibenarkan, kata Motzki, jika terbukti dengan jelas bahwa sebagian besar isnād telah dipalsukan dan bahwa tidak mungkin mendeteksi isnād-isnād yang dapat dipercaya. Akan tetapi, hal ini tidak terbukti dalam hadis. Hingga sekarang, pemalsuan isnād terbukti kebenarannya hanya pada kasus-kasus individual. Oleh karena itu, jika kita belum membuktikan kebalikannya maka kita harus melanjutkan asumsi bahwa sistem isnād secara umum dapat dipercaya (reliable) dan dapat dioperasikan, kecuali hanya di sekitar waktu ketika sistem itu baru muncul. ${ }^{22}$

${ }^{21}$ Cook, "Eschatology and the Dating of Traditions" dalam Princeton Papers in Near Eastern Studies 1, (1992), h. 40. Dalam pandangan Motzki, Schacht sebenarnya membatasi fenomena penyebaran isnād pada țabaqah sahabat, tetapi Cook mengeneralisasi teori ini untuk menentang reliabilitas isnād secara umum.

${ }^{22}$ Harald Motzki, "The Prophet and the Cat: On Dating Malik Muwatta' and Legal Traditions," dalamJSA122, (1998), h. 32. 


\section{Biografi dan Karya-karya Norman Calder}

Norman Calder dilahirkan pada tahun 1950 di Buckie, Skotlandia. Norman Calder melanjutkan kuliahnya ke Sekolah Tinggi Wadham, Oxford, pada tahun 1969. Ia mendapatkan penghargaan (Award) pertama kali dalam bahasa Arab dan bahasa Persia pada tahun 1972. Kemudian ia menghabiskan waktu empat tahun di Timur Tengah untuk mengajar bahasa Inggris. Sekembalinya dari Timur Tengah, ia mendaftarkan diri sebagai mahasiswa program Doktor, di bawah bimbingan John Wansbrough di School of Oriental and African Studies (SOAS). Disertasinya yang berjudul, "The Structure of Authority in Imami Shi'i Jurisprudence", adalah sebuah karya yang mengagumkan. ${ }^{23}$ Karya ini terus dijadikan rujukan oleh para sarjana Syi'ah kira-kira dua puluh tahun setelah ia menyelesaikan program Doktornya. Disertasi ini dan beberapa artikel yang diambil darinya, lebih jauh menegaskan wilayah hukum Syi'ah yang diabaikan di dunia akademik Barat. Ketertarikannya terutama adalah hubungan antara epistemologi dan autoritas. Ia menguji bagaimana para ahli hukum Syi'ah mengembangkan sebuah teori hukum yang melindungi peran mereka sebagai sarjana (ulama' fiqh) dan hak prerogatif mereka sebagai penafsir. Tema-tema ini dikembangkan dan diperluas dalam artikel-artikel belakangan, yang menitikberatkan kepada semacam tokoh yang bermacam-macam seperti al-Syafi'i, Sabzawari dan Khomaini.24

Norman Calder adalah seorang dosen senior di bidang bahasa Arab dan Studi-Studi Keislaman di Jurusan Middle Eastern Studies di Universitas Manchester. Ketika meninggal pada 13 Pebruari 1998 di usia 47, ia merupakan salah seorang sarjana terkemuka di bidang studi yurisprudensi Islam dan hermeneutika. Pada saat ia meninggal dunia, Norman Calder telah menjadi seorang sarjana terkemuka yang didiskusikan paling luas di bidang hukum Islam. Hal ini disebabkan karena karya ilmiahnya yang berjudul, Studies in Early Muslim Jurisprudence (Oxford, 1993), yang dengan berani telah menantang berbagai teori para ahli hukum Islam tentang asal mula hukum Islam. ${ }^{25}$

Meskipun ia menderita sakit menjelang ajalnya, ia menerima watak sakitnya. Ia tidak pernah menyerah kepada sakit yang dideritanya. Ia tetap me-

${ }^{23}$ Ibid.

24"Norman Calder (1950-1998)", dalam Islamic Law and Society 5, 3 (Leiden: Brill, 1998).

${ }^{25}$ Ibid. 
laksanakan berbagai kegiatan ilmiah seperti membaca, meneliti dan menulis hingga hari-hari kematiannya. Pikirannya yang tajam tidak berkurang oleh kelemahan badan dan fisiknya yang kian bertambah. Ia menaruh pekerjaanpekerjaannya agar dapat mempersiapkan karya-karya akademiknya yang masih tersisa untuk dapat dipublikasikan di kemudian hari. ${ }^{26}$

Sebagai seorang sarjana di bidang hukum Islam, ia meninggalkan beberapa karya yang nilai ilmiahnya sangat tinggi. Karya-karya Calder yang telah dipublikasikan di penerbit bertaraf internasional itu adalah:

1. Norman Calder, Studies in Early Muslim Jurisprudence, Clarendon Press, 1993.

Buku ini menawarkan sebuah teori yang koheren mengenai asal mula dan perkembangan awal Hukum Islam. Penulis buku ini mendasarkan argumentasinya dalam serangkaian paragraf yang representatif dari karya-karya di bidang hukum Islam di masa awal, sebagiannya diterjemahkan di sini untuk pertama kalinya. Bab-bab yang berturut-turut dalam buku ini menunjukkan kreativitas peradaban orang Muslim awal dalam bentuk sastra, norma-norma hukum, dan teknik penafsiran. Mengambil dari tradisi kesarjanaan Islam yang diwakili oleh tokoh-tokoh seperti Ignaz Goldziher, Joseph Schacht, and John Wansborough, Calder tampaknya sensitif juga terhadap perkembangan metodologi dan teknik berbagai bidang studi yang paralel antara studi Bible dan kependetaan.

Dengan mendasarkan semua generalisasi utamanya dalam rincian tektual yang tepat, ia membangkitkan berbagai perhatian sosial, politik, dan intelektual terhadap peradaban Muslim pada periode pembentukannya. Calder menunjukkan, beberapa konotasi yang biasa tidak pantas untuk memahami yurisprudensi orang Muslim pada masa awal. Teks-teks yang sampai ke tangan kita (survive) mengangkat dan merekam hidup-hidup tentang bagaimana masyarakat Muslim awal menciptakan simbol-simbol utama identitas mereka sendiri. ${ }^{27}$

2. Norman Calder, Studies in Islamic and Middle Eastern Tekss and Traditions in Memory of Norman Calder, By. Norman Calder, Alexander Samely, Jawid Ahmad Mojaddedi, Oxford University Press, 2000.

Buku ini merefleksikan ketertarikan dan sumbangan akhir Norman Calder sendiri. Ia mencakup berbagai artikel yang ditulis oleh para sarjana yang ter-

\footnotetext{
${ }^{26}$ Ibid.

${ }^{27}$ http://books.google.co.id/books/about/Studies_in_early_Muslimjurisprudence.html?id =3QTY AAAAMAAJ\&redir esc=y.
} 
kenal, seperti Calder, karena pendekatan mereka yang berpengalaman, njelimet, dan menantang teks-teks Arab dan Islam. Makalah-makalah itu mengkaji berbagai topik yang menarik masyarakat di bidang kebudayaan Timur Tengah, dan pada dasarnya sama dengan berbagai koleksi, karya-karya hasil konferensi, dan Festschriften. Yang direpresentasikan adalah murid-muridnya terlebih dahulu, para koleganya yang bekerja di bidang studi kependetaan, yang telah menginformasikan karyanya sendiri. Topik-topik itu meliputi transformasi tradisi Yahudi pada masa Islam awal: kasus Enoch/Idris, narasi dan doktrin dalam kisah pertama Masnavi Jalaludin Rumi, fikih untuk para pemula: Teks Anatolia tentang jihad, riset tentang kelompok Minoritas Muslim: beberapa refleksi tentang bidang kerja di Inggris, peraikahan rusak dalam fikih Hanafi klasik, dan apakah hak-hak asasi dapat hidup berdampingan dengan agama?28

\section{Norman Calder, Classical Islam: A Sourcebook of Religious Literature.} Routledge, 19 September 2003.

Buku sumber yang menentukan ini menghadirkan lima puluh terjemahan baru teks-teks Islam kunci yang autoritatif. Diedit dan diterjemahkan oleh tiga spesialis terkemuka dan dikontekstualisasikan dengan jelas untuk para mahasiswa tingkat pengenalan, ia mengilustrasikan pertumbuhan pemikiran Islam dari asal pada abad ke-7 melalui periode abad pertengahan. Delapan bagian yang terorganisisr secara tematis mencakup berbagai topik seperti al-Qur'an dan penafsirannya, sejarah hidup Muhammad, hadis, hukum, ritus-ritus, tasawuf dan sejarah Islam. Di antara berbagai seleksi adalah semacam mutiara seperti uraian Ibnu 'Abbas tentang perjalananan yang menyenangkan, al-Taftazani tentang tidak diciptakannya al-Qur'an sebagai kalam Allah, al-Farabi tentang kemampuan jiwa, dan menggali dari Matsnavi Rumi. Dilengkapi dengan daftar glosarium yang cukup membantu, daftar pustaka yang luas dan kata pengantar yang menjelaskan masing-masing bagian, buku ini menfokuskan pada gaya atau aliran sastra kesarjanaan Muslim, yang di dalam berbagai variasi kreatifnya, doktrin Islam mengambil bentuk dan menjadi matang. Dengan beberapa kutipan yang diterjemahkan di sini pertama kali ke dalam bahasa Inggris, Perancis dari sumber-sumber berbahasa Arab dan Persia, Islam klasik adalah sumber

\footnotetext{
${ }^{28} \mathrm{http}: / /$ books.google.co.id/books/about/Studies in_Islamic and Middle Eastern_Te.html?id $=3 \mathrm{R}$ piAAAAMAAJ\&redir $\mathrm{esc}=\mathrm{v}$.
} 
pokok bagi sebuah penghargaan tentang Islam awal, Islam abad pertengahan dan warisannya. ${ }^{29}$

4. Norman Calder. Interpretation and Jurisprudence in Medieval Islam, (eds.) Jawid Mojaddedi and Andrew Rippin. Ashgate Variorum, 2006.

Buku yang terdiri dari dua puluh satu artikel ini merepresentasikan kekayaan dan keragaman dari oeuvre Calder, dari riset doktornya yang pertama tentang Islam Syi'ah hingga tulisan-tulisannya yang lebih filosofis belakangan ini tentang hermenetika Sunni, selain sejumlah studi tentang sejarah dan yurisprudensi Islam awal. Penelitian pionir Calder yang didasarkan pada pembacaan yang sensitif atas teks-teks abad pertengahan yang diinformasikan secara penuh oleh teori kritis kontemporer, seringkali menantang berbagai asumsi yang mapan saat itu. Ia dikenal khususnya karena telah mendesak taksiran dari berbagai prasangka yang dipegangi secara luas yang menaksir terlalu rendah tingkat kreativitas kesarjanaan Islam abad pertengahan. Beberapa artikel dalam buku ini telah menjadi klasik untuk bidang-bidang studi yurisprudensi Muslim dan hermeneutika.

5. Norman Calder, Islamic Jurisprudence in the Classical Era, Cambridge: Cambridge University Press, 2010.

Sepuluh tahun setelah kematiannya di usia yang terlalu muda, Norman Calder masih dianggap sebagai seorang bintang di bidang hukum Islam. Pada saat itu, ia adalah orang di antara sedikit sarjana Barat yang mulai tertarik dengan mata kuliah itu. Pada beberapa tahun yang menyelangi, banyak yang berubah, dan hukum Islam sekarang dipahami sebagai dasar bagi ketertarikan apapun dengan studi Islam, sejarahnya, masyarakatnya, karya Dr. Calder ini adalah integral dengan ketertarikan itu. Dalam buku ini, Colin Imber telah meletakkan bersama-sama dan mengedit empat essai Calder yang tidak pernah dipublikasikan sebelumnya. Secara tajam, mereka mengkategorikan dan menganalisa genre yang berbeda mengenai literatur hukum Islam yang diproduksi antara abad sepuluh dan empatbelas, dengan menunjukkan fungsi apa yang mereka berikan, baik dalam menjaga hukum Islam, tradisi keagamaan maupun dalam kehidupan keseharian masyarakat mereka. Esai-esai itu juga menguji status dan peranan para ahli hukum sendiri dan secara khusus disambut baik

${ }^{29} \mathrm{http}: / /$ books.google.co.id/books/about/Classical Islam.html?id=JditUTYSLIUC\&redir esc=v. 
karena telah memberi jawaban yang jelas atas berbagai persoalan kontroversial tentang sejauh mana hukum Islam dan pemikiran hukum telah berubah selama beberapa abad, dan sejauh mana ia mampu beradaptasi dengan lingkungan baru. Dalam pendahuluan buku itu, Robert Gleave menilai kedudukan dan pentingnya karya Calder di bidang studi hukum Islam. Ini adalah buku penggalian pertama salah seorang sarjana paling penting dari generasinya. ${ }^{30}$

\section{E. Norman Calder tentang Common Link sebagai Tokoh yang Kebal dari Kritik}

Sama dengan Michael Cook, Norman Calder juga meragukan validitas metode common link dan informasi sejarah yang didapatkan melaluinya. Akan tetapi, untuk memahami maksud dari kritiknya terhadap teori tersebut dengan lebih baik, sebelumnya penulis akan terlebih dahulu membicarakan pandangannya mengenai proses yang memproduksi teks-teks dan bahan-bahan tertulis, termasuk di dalamnya adalah teks-teks hadis.

Dalam Studies in Early Muslim jurisprudence, ${ }^{31}$ Calder mengkaji enam teks hukum dari tiga aliran hukum Islam. Teks-teks itu adalah: Mudawwanah Sahnun, Muwatța' Malik, beberapa teks Hanafi, Kitāb al-Umm al-Syafi'i, Mukhtașar Muzani, dan Kitāb al-Kharaj Abu Yusuf. Kajian Calder dalam buku ini, terutama berpijak pada analisa sastra atas teks-teks fiqh yang paling pokok dan dilanjutkan dengan diskusi umum mengenai yurisprudensi Islam pada abadabad awal tahun hijriah. Ketika menilai bentuk sastra dari karya-karya itu pada saat kemunculannya, Calder menyatakan bahwa dikotomi tradisional antara periwayat lisan (oral) dan tertulis (written) seharusnya tidak digambarkan sedemikian tajamnya.

Teks-teks yuristik, dalam bahasa yang dipakai untuk mengungkapkan periwayatan hadis, seperti haddatha, qala, dan akhbara, membuktikan adanya aktivitas lisan yang signifikan, yakni kreativitas dan periwayatan. Selain itu, Calder menekankan pentingnya mengakui bahwa teks-teks tertulis seperti yang ada sekarang ini tidak hanya merepresentasikan sebuah bagian dari korpus

\footnotetext{
${ }^{30} \mathrm{http}: / /$ books.google.co.uk/books/about/Islamic Jurisprudence in the Classical E.html?id== 2sk BdOJAicOC.

${ }^{31}$ Norman Calder, Studies in Early Muslim Jurisprudence. Dalam buku ini, Calder memulai kajiannya dari aliran fiqh Maliki, lalu Abu Hanifah, dan setelah itu, Syafi'i.
} 
tertulis pada saat itu, tetapi juga sebuah bagian yang lebih kecil dari aktivitas lisan. Lingkungan Arab Islam hingga awal dekade abad ketiga hijriah adalah lingkungan yang sangat produktif, baik bagi literatur lisan maupun tertulis. Literatur lisan, setidaknya dalam konteks yuristik, sering merupakan produk dari sebuah proses diskursif. Sedangkan literatur tertulis memperlihatkan adanya aktivitas lisan ini dan tampaknya mereka juga berupaya menciptakannya kembali. Buku-buku merupakan literatur kedua setelah periwayatan lisan dan pada awalnya ada dalam bentuk buku-buku catatan pribadi. ${ }^{32}$

Pemilik sebuah buku catatan, lanjut Calder, mengontrol isinya. Berbagai kelompok yang tertarik menulis sama' (pendengaran) mereka dari si fulan dan si fulan. Tidak ada alasan untuk menganggap bahwa sebuah sama' seseorang sama dengan sama' orang lain meskipun dari guru yang sama. Dan, sangat mungkin bahwa dua pendengar pada majlis yang sama akan membuat catatan berbeda. Mereka merekam ucapan guru mereka dan menuliskannya dengan kata-kata mereka sendiri. Bahkan mungkin mereka membaca kembali catatancatatan yang berbeda itu di hadapan guru mereka dan kemudian mendapat persetujuannya. Akhirnya, mereka menyimpan dan meriwayatkan bahan-bahan mereka sendiri, bukan buku dari guru mereka.

Otoritas atau keterampilan para periwayat semacam inilah yang akhirnya menimbulkan sebuah teks tertentu yang kemudian disandarkan kepada seorang guru yang disebutkan namanya. Antara buku catatan yang pertama dan teks tertentu ada beberapa tahap yang dialami. ${ }^{33}$ Oleh karena itu, menurut Cader, yang memproduksi buku-buku catatan ini adalah para murid, bukan para guru. Buku-buku catatan itu mungkin disebarkan atau dihancurkan, namun kandungannya disalin ke buku-buku catatan yang lain walaupun bukan tidak mungkin bahwa bentuk dan kandungannya mengalami berbagai perubahan dalam proses penyalinannya. Pada akhirnya, sebuah sistem kontrol dikembangkan di mana seorang guru mengarang dan menerbitkan buku-bukunya dengan cara mempekerjakan para sekretarisnya atau dengan cara meminta para muridnya untuk membandingkan catatancatatan mereka dengan bukunya. ${ }^{34}$ Dengan demikian, kata Calder, pada abad ketiga Hijriah terdapat suatu pergeseran dari

32 Ibid., h. 161-173; Herbert Berg, The Development of Exegesis, h. 45-46.

${ }^{33}$ Norman Calder, Studies in Early Muslim Jurisprudence, h. 173-174.

${ }^{34} \mathrm{Ibid}$. h. 179-180. 
lingkungan lisan yang dominan ke lingkungan tertulis melalui mediasi bukubuku catatan ini, seperti dikatakan Calder berikut ini:

"The scholar's notebook and the institutional redaction are then the two basic types of early juristic literature. Of the former there may be no extant examples. Their existence, however, is securely inferred from the forms and sometimes from then express words of institutional redactions, and it is confirmed by numerous references in biographical and other literature." 35

Lebih jauh, Calder berkeyakinan bahwa tidak hanya enam buku yang dikajinya, tetapi juga seluruh literatur Arab-Islam yang diklaim berasal dari abad pertama, kedua, dan awal abad ketiga hijriah telah mengalami pertumbuhan organis dan proses redaksional multi-level.

Teori pertumbuhan organik bagi literatur yuristik lisan dan tertulis ini digunakan oleh Calder sebagai latar belakang bagi upayanya untuk menunjukkan bahwa matan hadis yang sama, yang memiliki seorang common link bukan karena hadis itu disebarluaskan oleh periwayat yang berperan sebagai common link (atau beberapa muridnya), melainkan sebagai akibat dari sebuah skenario yang sangat berbeda. Oleh karena itu, Calder mengingkari bahwa metode common link itu dapat dipakai untuk mengetahui penanggalan hadis. Baginya, fenomena common link sebagai satu ciri yang terdapat dalam literatur hadis sangat terkait dengan metode kritik isnād yang berlaku di kalangan para ahli hukum dan yang lainnya pada paro kedua abad ketiga Hijiriah. ${ }^{36}$

Adapun yang dimaksud Calder dengan skenario yang sangat berbeda adalah sebagai berikut: jika ada sebuah teks (matan) hadis yang diterima oleh beberapa kelompok yang berbeda dalam Islam, masing-masing kelompok cenderung merebut (capture) matan hadis yang orisinal dan memberinya isnād yang merefleksikan kelompok mereka. Akan tetapi, karena hampir semua kelompok mengakui dan mengenal para pahlawan yang umum pada masa nabi maka (biasanya) pada level tabi'in, isnād cenderung mulai bertemu. ${ }^{37}$

Secara lebih khusus, kata Calder, skenario semacam ini dapat dilihat ketika ada kompetisi antara berbagai kelompok yang masing-masing terlibat dalam proses kritik isnād satu sama lain. Lagi-lagi, karena mereka sama-sama memiliki

${ }^{35}$ Ibid., h. 163.

36Ibid., h. 240; Motzki, "The Prophet and the Cat:, h. 36.

${ }^{37}$ Norman Calder, Studies in Early Muslim Jurisprudence, h. 237. 
rasa hormat pada generasi sahabat dan tabiin, mereka cenderung "menggeser" sebuah hadis dengan cara menghancurkan salah satu dari dua periwayat: periwayat ketiga atau keempat, yang berfungsi sebagai periwayat dari common link. Misalnya, aliran X menjelaskan bahwa hukum tentang satu masalah adalah begini atau begitu berdasarkan sebuah hadis dengan isnād berikut ini: Nabi -A-B-C-D-E. Sementara itu, aliran Y sebagai lawan dari aliran X mengetahui bahwa hukum tentang masalah yang dibicarakan tidak begini atau begitu, sebagaimana yang dijelaskan oleh aliran X. Akibatnya, aliran Y terpaksa mengkritik isnād hadis ini. Akan tetapi, ia tidak dapat mengkritik nabi, sahabat atau tabiin dengan alasan yang telah disebutkan di depan. Yang dapat dikritik olehnya adalah C, periwayat ketiga, dengan menyatakannya sebagai periwayat yang memiliki hafalan yang buruk. ${ }^{38}$

Karena mengetahui lemahnya hubungan periwayatan W - C, kelompok A yang setuju dengan hadis tersebut memperkuat posisi mereka dengan menemukan isnād baru yang menunjukkan adanya hubungan periwayatan B - J di mana J dikenal sebagai periwayat yang memiliki daya hafalan yang luar biasa kuat. Sementara kelompok B yang menolak hadis ini berusaha menggantinya dengan isnād lain yang lemah: $\mathrm{B}$ - K, di mana $\mathrm{K}$ adalah pembuat bid'ah yang terkenal. Atau lebih buruk lagi, mereka mengemukakan isnād B - K- J, di mana J yang dapat dipercaya sebenarnya dikelabui oleh K, pembuat bid'ah itu. Aliran A senantiasa memperbaiki periwayat yang lemah dan mencoba mengemukakan isnād yang berbeda sampai kelompok B menyerah.

Dengan demikian, kelompok yang ingin menerima hadis tersebut bereaksi dengan cara memproduksi isnād-isnād baru di mana para periwayat yang diserang oleh kelompok lain diganti dengan periwayat lain yang lebih dapat dipercaya. Jika isnād-isnād ini ditolak lagi, maka diciptakanlah isnād-isnād baru untuk memperbaikinya. Sebaliknya, kelompok yang menolak hadis tersebut juga memalsukan hadis dengan memakai periwayat-periwayat lemah di mana setelah itu mereka mengkritiknya. ${ }^{39}$ Akibatnya, pro dan kontra kritik isnād diarahkan kepada para periwayat lemah yang berada pada generasi ketiga atau keempat yang terdapat dalam isnād hadis. Hal ini, menurut Calder, menyebabkan terjadinya fenomena common link yang sebenarnya tidak menunjukkan asal-usul matan sebuah hadis, tetapi lebih merefleksikan proses kritik isnād dan kompetisi antar berbagai kelompok Islam pada paroh kedua abad ketiga atau

${ }^{38}$ Ibid.

${ }^{39}$ Motzki, "The Prophet and the Cat," h. 37. 
sesudahnya. ${ }^{40}$ Bagi Calder, common link dalam faktanya bukan orang yang memalsukan atau menyebarkan hadis, melainkan seorang tokoh terdahulu sebelum tokoh yang menjadi fokus pertikaian dalam kritik isnād satu sama lain. Meskipun demikian, Calder tidak beranggapan bahwa metode common link tidak memiliki nilai kebenaran sama sekali karena dalam beberapa kasus metode ini dapat digunakan. ${ }^{41}$

Akan tetapi, ketika Calder menggunakan metode common link pada Bab II bagian empat dalam bukunya, jelas bahwa ia tidak memahami fungsi fenomena common link sebagaimana dipahami para sarjana Barat. Pada halaman 37-38, misalnya, Calder berbicara mengenai beberapa periwayat yang menduduki posisi common link, padahal sebenarnya yang ada hanyalah seorang common link, yakni Ibnu Wadhdhah. Sedangkan isnād campuran yang mengungkapkan hubungan periwayatan Ibnu Wadhdhah - Yahya - Malik dan hubungan periwayatan melalui Ubaidillah bin Yahya - Yahya - Malik, dalam isnād itu yang menjadi common link adalah Yahya. Akan tetapi, Calder masih mempertentangkan bahwa Yahya kemungkinan adalah pengarang al-Muwatta'. Setidaknya, demikianlah yang dikatakan Motzki. ${ }^{42}$

Jika model interpretasi Calder atas fenomena common link itu tepat dan kemudian ia diterapkan pada bundel isnād hadis tentang kucing yang dikaji oleh Calder, ${ }^{43}$ di mana Malik tampak sebagai periwayatnya maka muncul beberapa persoalan: pertama, apakah Malik adalah tokoh yang dianggap oleh semua kelompok ulama fiqh sebagai tokoh yang kebal dari kritik? Asumsi ini ternyata tidak terbukti karena memang tidaklah demikian kenyataannya. Kedua, kelompok mana yang menolak hadis ini? Tampaknya tidak ada satu aliran pun yang menolak hadis tersebut. Sebab, aliran Maliki, Syafi'i, dan Hanbali samasama menerimanya karena telah terbukti bahwa hadis itu terdapat dalam kitab Muwatta' Yahya dan al-Syaibani, juga dalam kitab al-Umm dan Musnad Ibnu

\footnotetext{
${ }^{40}$ Sebagaimana terdapat dalam uraiannya berikut ini: "This leads to the common link phenomenon, which reflects nothing whatsoever about the origins of the matn of a hadith: it reflects isnad criticism and competition in or after the second half of the third century; Ibid.

${ }^{41}$ Sebagaimana dikatakannya sendiri, "The Common-Link Theory is not quite an aberration of scholarship, for it has some uses." Calder, Studies in Early Muslim Jurisprudence, h. 240; Tentang hal ini, baca juga Kamaruddin Amin. "Western Method of Dating vis-a-vis Ulumul Hadits," h. 14-15.

${ }^{42}$ Motzki, "The Prophet and the Cat," h. 36.

${ }^{43}$ Dalam Muwatta', ada sebuah hadis Nabi yang mengizinkan air dalam sebuah bejana yang telah diminum oleh seekor kucing untuk dipakai wudhu' karena kucing adalah hewan piaraan; ibid., h. 23 .
} 
Hanbal. Bahkan, aliran Hanafi pun tidak menolaknya, walaupun mereka mungkin tidak begitu menyukainya, sebagaimana terbukti dalam Muwatta' alSyaibani. Ketiga, siapa yang dituduh sebagai para periwayat yang lemah dalam bundel isnād hadis tersebut? Berdasarkan karya-karya biografis, tak seorang pun dari enam belas periwayat hadis itu yang meriwayatkannya dari Malik dan tak seorang pun dari orang-orang yang muncul dalam isnād setelah meraka tergolong periwayat lemah. Mereka semua dinyatakan "dapat dipercaya" atau "sangat dapat dipercaya" (șaduq atau thiqah), baik secara umum maupun secara khusus, yakni hubungan periwayatan mereka dari Malik. ${ }^{44}$

Dengan bukti-bukti di atas, menurut Motzki, interpretasi dan skenario Calder tidak dapat dipertahankan. Skenario tersebut tidak mampu menjelaskan fenomena common link. Kritik tajam Motzki atas Calder itu tergambar dalam kata-katanya berikut ini:

"It thus seems that Calder's "scenario" does not work. It can not explain the common-link phenomenon. It is, therefore, reasonable to ignore his ideas and to proceed on the basis of the assumption that a common link is a central figure in the propagation of a hadith. In the case of the hadith about the cat, Malik plays this role." 45

(Dengan demikian, tampak bahwa skenario Calder tidak bekerja. Ia tidak menjelaskan fenomena common link. Oleh karena itu, adalah masuk akal untuk mengabaikan ide-idenya dan meneruskan berdasarkan asumsi bahwa seorang common link adalah tokoh sentral dalam perkembangan sebuah hadis. Dalam kasus hadis tentang kucing, Malik memainkan peranan ini).

\section{F. Persamaan dan Perbedaan Pandangan Neo-Skeptisisme Cook dan Calder}

Analisa perbandingan antara pandangan neo-skeptisisme Cook dan Calder menunjukkan bahwa dalam banyak hal, interpretasi Cook dan Calder atas fenomena common link memiliki persamaan-persamaan dan perbedaan-perbedaan. Di antara persamaannya adalah bahwa Cook dan Calder sama-sama memperluas sikap skeptisisme atas isnād hadis melebihi skeptisisme Schacht dan Goldziher. Dalam faktanya, keraguan dua tokoh itu atas validitas teori common

${ }^{44}$ Ibid., h. 37.

${ }^{45}$ Ibid, h. 37-38. 
link merupakan implikasi logis dari sikap skeptisisme mereka atas autentisitas isnād. Jika seseorang meragukan autentisitas sistem isnād, maka tentunya Ia meragukan seluruh naskah atau teks hadis awal yang memakai isnād, sebagai alat untuk membuktikan autentisitasnya. ${ }^{46}$ Ini sama-sama terjadi pada Cook dan Calder yang mempunyai kecenderungan untuk mendekonstruksi atau menghancurkan informasi sejarah mengenai dating tradition (menaksir umur hadis) berdasarkan metode common link.

Di sisi lain, Berg menyebut pandangan Cook dan Calder sebagai pandangan hiper-skeptisisme yang merupakan akibat dari upaya mempertahankan pendekatan neo-skeptisismenya atas teks-teks awal hadis. Hiper-skeptisisme cenderung menolak bukti apapun yang bertentangan dengan pendekatan neoskeptisnya. ${ }^{47}$

Sedangkan perbedaan pandangan neo-skeptisisme Cook dan Calder di antaranya adalah: pertama, Cook menolak sama sekali validitas metode common link karena metode itu tidak menggambarkan bahwa sebuah hadis bersumber dari seorang periwayat kunci tertentu, yang menduduki posisi common link dalam satu bundel isnādnya, tetapi karena tiga skenario penyebaan isnād dalam skala besar telah terjadi di zaman awal Islam. Sayangnya, tiga skenario penyebaran isnād, yang menurut Cook merupakan penjelasan dari teori the spread of isnād, telah merusak teori common link dan membuatnya tidak dapat dioperasikan lagi. Sementara Calder menyatakan bahwa metode common link terkadang bisa digunakan untuk menelusuri asal mula hadis, tetapi terkadang metode itu tidak dapat digunakan. Kapan metode common link dapat digunakan dan kapan ia tidak dapat digunakan sebagai alat untuk menelusuri asal-usul dan sumber hadis, Calder tidak memberikan penjelasan yang cukup memadai.

Kedua, Cook berangkat dari kajian teologi Islam, yakni mengkaji persoalan asal mula dan perkembangan kontroversi aliran teologi, Jabariyah dan Qadariyyah pada masa Islam awal, seperti yang telah dilakukan oleh Joseph van Ess, sementara Calder berangkat dari kajian hukum Islam, seperti yang dilakukan oleh Joseph Schacht dan Yasin Dutton. Calder mengkaji beberapa literatur fikih paling berpengaruh dalam tiga aliran hukum fiqh, seperti aliran hukum Hanafi, Maliki, dan Syafi'i.

${ }^{46}$ Herbert Berg, The Development of Exegesis, h. 48.

${ }^{47}$ Ibid.

JURNAL THEOLOGIA — Volume 28, Nomor 1, Juni 2017 
Ketiga, Cook tidak melakukan dating (menaksir umur) hadis Nabi Muhammad., apakah umur hadis itu setua generasi tabiin, atau tabiit tabiin karena ia meragukan metode common link untuk menelusuri sumber dan kepengarangan hadis, tetapi cenderung menghancurkan atau mendekonstruksi dating hadis. Sementara itu, Calder telah melakukan dating hadis ke masa yang lebih belakangan daripada dating hadis yang telah dilakukan oleh Schacht dan Juynboll sekalipun. Sebagai contoh, ia menyatakan bahwa kitab Muwatța' yang ada sekarang ini bukan karya Imam Malik bin Anas, tetapi produk yang ditulis di Cordoba pada akhir abad 3 H. oleh muridnya, Yahya bin Yahya al-Layts (230 H). Namun hal ini telah dibantah oleh Yasin Dutton, dengan bukti-bukti sebagai berikut: 1) Terdapat penggalan teks yang ditulis di atas daun lontar yang merujuk kepada pendapat di atas yang oleh Abbott diberi tahun penulisan menurut bukti tekstual, menurut kondisi masa Malik sendiri pada paruh kedua abad ke-2 H. 2) Dutton memiliki penggalan riwayat dari Ali bin Ziyad berbentuk kertas kulit yang ditulis pada $288 \mathrm{H}$ yang penggalan riwayat ini merujuk kepada pendapat di atas. 3) Perbandingan terhadap riwayat Ibnu Ziyad dengan riwayatriwayat lainnya baru-baru ini telah tersedia, baik sepenuhnya atau sebagian dalam bentuk catatan, khususnya riwayat-riwayat dari Yahya bin Yahya al-Layts, Asy-Syaybani, al-Qa'nabi, Suwaid dan Abu Mus'ab menunjukkan bahwa seluruh enam riwayat itu memiliki pokok isi yang sangat mirip dan karenanya dengan jelas merepresentasikan satu teks. 4) Dutton memiliki bukti sekunder berupa literatur biografis yang mnegungkapkan sebagian dari sejumlah orang yang meriwayatkan al-Muwatța' secara langsung dari Malik dan juga sebagian dari sejumlah komentar yang ditulis di dalamnya sebelum tahun yang diajukan oleh Calder bagi kemunculan kitab itu sekitar $270 \mathrm{H}^{48}$

\section{G. Kesimpulan}

Beberapa kesimpulan dapat diambil setelah membahas dan mengkaji pandangan neo-skeptisisme Cook dan Calder terhadap hadis Nabi Muhammad.

Pertama, pandangan Michael Cook dan Norman Calder tampak lebih skeptis daripada Goldziher dan Schacht dalam memandang autentisitas hadis.

\footnotetext{
48Yasin Dutton, Amal Mula Hukum Islam: Alqur'an, Muwatta' dan Praktek Madinah, cet. 1 (Yogyakarta: Islamika, 2003).
} 
Oleh karena itu, keduanya dapat dimasukkan pada fase keempat, yakni fase neoskeptisisme. Secara umum, perhatian Cook dan Calder tertuju pada autentisitas, kronologi dan kepengarangan hadis. Persamaannya adalah bahwa keduanya menolak validitas teori common link jika dijadikan metode untuk membuktikan dan menelusuri asal muasal dan sumber hadis. Bagi Cook, Fenomena common link tidak menunjukkan bahwa sebuah hadis benar-benar bersumber dari seorang periwayat kunci. Menurutnya, metode common link yang dikembangkan oleh Juynboll tidak dapat dipakai untuk menelusuri asal-usul, sumber, dan kepengarangan hadis pada masa awal Islam. Sementara Calder mengingkari bahwa metode common link itu dapat dipakai untuk mengetahui penanggalan hadis. Baginya, fenomena common link sebagai satu ciri yang terdapat dalam literatur hadis sangat terkait dengan kompetisi antar berbagai kelompok di kalangan para ahli hukum dan yang lainnya pada paroh kedua abad ketiga hijrah yang masing-masing terlibat dalam proses kritik isnād satu sama lain.

Kedua, analisa perbandingan antara pandangan neo-skeptisisme Cook dan Calder menunjukkan bahwa interpretasi Cook dan Calder atas fenomena common link memiliki persamaan dan perbedaan. Di antara persamaannya adalah bahwa baik Cook maupun Calder sama-sama memperluas sikap skeptisisme atas isnād hadis melebihi skeptisisme Schacht dan Goldziher. Dalam faktanya, keraguan keduanya atas validitas teori common link merupakan implikasi logis dari sikap skeptisisme mereka atas autentisitas isnād. Jika seseorang meragukan sistem isnād, maka tentunya ia meragukan seluruh naskah atau teks hadis awal yang memakai isnād, sebagai alat untuk membuktikan autentisitasnya. Ini sama-sama terjadi pada Cook dan Calder yang mempunyai kecenderungan untuk "menghancurkan" informasi sejarah mengenai penanggalan hadis berdasarkan metode common link. Di sisi lain, Berg menyebut sikap Cook dan Calder sebagai hiper-skeptisisme yang merupakan akibat dari upaya mempertahankan pendekatannya atas teks-teks awal. Hiper-skeptisisme cenderung menolak bukti apapun yang bertentangan dengan pendekatan skeptisnya.

Ketiga, sedangkan perbedaan pandangan neo-skeptisisme Cook dan Calder di antaranya adalah: pertama, Cook menolak sama sekali validitas metode common link karena metode itu tidak menggambarkan bahwa sebuah hadis bersumber dari seorang periwayat tertentu, sementara Calder menyatakan bahwa metode common link terkadang bisa digunakan untuk menelusuri asal mula hadis, tetapi terkadang metode itu tidak dapat digunakan. Kedua, Cook 
berangkat dari kajian teologi Islam seperti yang dilakukan oleh Joseph van Ess, sementara Calder berangkat dari kajian hukum Islam, seperti yang dilakukan oleh Schacht dan Yasin Dutton. Ketiga, Cook tidak melakukan dating terhadap hadis Nabi Muhammad., tetapi cenderung menghancurkan atau mendekonstruksi dating hadis. Sementara Calder melakukan dating hadis lebih belakangan daripada dating yang dilakukan oleh Schacht dan G.H.A. Juynboll sekalipun.]

\section{DAFTAR PUSTAKA}

Amin, Kamaruddin. "Western Method of Dating vis-a-vis Ulumul Hadits: Refleksi Metodologis atas Diskursus Kesarjanaan Hadits Islam dan Barat." UIN Alaudin Makasar: Pidato Pengukuhan Jabatan Guru Besar, 2010. Makalah belum diterbitkan.

Azami, M.M., Studies in Early Hadith Literature with a Critical Edition of Some Early Texts. Beirut: al-Maktab al-Islami, 1968.

Berg, Herbert, The Development of Exegesis in Early Islam: The Authenticity of Muslim Literature from the Formative Period, Surrey: Curzon Press, 2000.

Calder, Norman, Studies in Early Muslim Jurisprudence, Oxford: Oxford University Press, 1993.

Studies in Islamic and Middle Eastern Texts and Traditions in Memory of Norman Calder. by. Norman Calder, Alexander Samely, Jawid Ahmad Mojaddedi, Oxford University Press, 2000.

Classical Islam: A Sourcebook of Religious Literature. Routledge, 2003.

Interpretation and Jurisprudence in Medieval Islam. Jawid Mojaddedi and Andrew Rippin (eds.), Ashgate Variorum, 2006.

Islamic Jurisprudence in the Classical Era. Cambridge: Cambridge University Press, 2010.

Cook, Michael A., Early Muslim Dogma: A Source Critical Study. Cambridge: Cambridge University Press, 1981.

"Eschatology and the Dating of Traditions" dalam Princeton Papers in Near Eastern Studies 1, (1992). 
Oposisi Penulisan Hadits di Masa Islam Awal, terj. Ali Masrur. Bandung: Marja Nuansa Cendekia, 2012.

http://en.wikipedia.org/wiki/Michael_Cook_\%28historian\%29.

http://books.google.co.id/books/about/Studies_in_early

Muslim_Jurisprudence.html?id=3QT YAAAAMAAJ\&redir_esc=y.

http://books.google.co.id/books/about/Studies in Islamic and Middle_Eastern_

Te.html?id= 3RpjAAAAMAAJ\&redir_esc=y.

http://books.google.co.id/books/about/Classical

Islam.html?id=JdjtUTYSLIUC\&redir esc $=y$.

http://books.google.co.uk/books/about/Islamic Jurisprudence in the Classical E.html?id==2sk BdOJAicOC.

Joseph Schacht, The Origins of Muhammadan Jurisprudence. Oxford: Clarendon Press, 1950.

Jujun S. Suriasumantri, "Penelitian Ilmiah, Kefilsafatan, dan Keagamaan: Mencari Paradigma Kebersamaan, " dalam Mastuhu dan M. Deden Ridwan (ed.), Tradisi Baru Penelitian Agama Islam: Tinjauan antar Disiplin Ilmu, Bandung: Nuansa, 2001.

Juynboll, G.H.A., "Some Isnad-Analytical Methods Illustrated on the Basis of Several Women Demeaning Sayings from Hadith Literature", dalam AlQantara. Revista de Etudos Arabes, 10, Fasc. 2, Madrid (1989) dan dalam Beberapa Kajian Indonesia dan Islam, terj. Lilian D. Tedjasudjana. Jakarta: INIS, 1991.

Masrur, Ali, Teori Common link G.H.A Jicynboll: Melacak Akar Kesejarahan Hadits Nabi saw., Yogyakarta: LKiS, 2007.

Motzki, Harald, "The Prophet and the Cat: On Dating Malik Muwatta' and Legal Traditions," dalam JSAI, 22, 1998. 
